\title{
SILK ROAD BOOKS LITERARY REVIEW
}

June 2016

\section{Afghan History through Afghan eyes The Afghan way of war}

Pages 1-2

Pages 2-7

Ratings:

- Great Read

- Thought Provoking

- Good

- Could be better

- Utter rubbish

\section{Afghan History through Afghan Eyes edited by Nile Green} Hurst (2016)

\section{Rating: Great Read}

This is a fascinating book based on an academic conference that provides the ground work for more research to be undertaken on Afghanistan based on Afghan and South Asian source materials. Amongst the works highlighted during the nineteenth century is the notable work by an Afghan monarch as Green Nile writes in the introduction "The most remarkable historical work to emerge from these interactions was the 'autobiography' of the ruler Shah Shuja (r.18039,1839-1842) who after being overthrown by a rival Durrani relative was returned to the throne by the British during the First Anglo-Afghan war. As an example of dialogical historiography, the text was written in the mid-1820s during the years of exile that Shah Shuja' spent in Punjab before being translated into English (and then German) by two European military officers."

When Britain invaded Afghanistan and put poor King Shuja on the throne, all the king's men and horses could not put the British army back together again from the drubbing the Brits received from the Afghans. As a consequence literature on the first Afghan war from the Afghan side was produced: "as in the case of MuhammedGhulamGhulami's Jang-nama ('book of war') an epic Persian poem on the First Anglo-Afghan war composed by one of its participants, and Mawlana Hamid Kashmiri's Akbar-nama ('book of Akbar') focusing on the heroic deeds of the Afghan General Wazir Akbar Khan (1816-1845). If there is one weakness in the book it is that there are few quotes from these works to enliven the text. This is also a failing of virtually all other books produced covering the first Anglo Afghan war. While some recent works produced by British historians mention the Jang-Nama they do not quote from either the Jang Nama. Hopefully Mr Green will be able to remedy this by producing a follow up work with greater analysis of the Jang Nama. 
Diaspora writers of Afghan origin in what was then British India flourished: "the biographies of individual Afghans appeared in Urdu biographical anthologies of scholars and holy men, which placed migrant Afghans into the history of Muslim India rather than Afghanistann. One example is Qazi Muhammad 'Abd all-Haq Kabuli (d.1903), who after leaving his native Kabul to study in India settled in the former Indo-Afghan state of Bhopal, where he gained many followers and in 1879 played host to Jamal al-Din al-Afghani."

Green writes further: "While it is unclear to what extent these Urdu texts circulated in Afghanistan, it seems lkely that they were read by (and in some cases written by) members of the Afghan diaspora communities of India as well as by readers in cities such as Kabul and Qandahar who were exposed to Urdu through trade and education in India." My own family resided in the Afghan diaspora community of Ludhiana in Eastern Punjab since they were descendants of Shah Shuja followers. About Ludhiana Green writes as follows: "By the 1930s, for example, Afghan exiles were publishing the newspaper Ittihad-I Afghan (Afghan Unity) from the Punjabi city of Ludhiana." Sadly such communities were snuffed out by partition violence.

There are many other interesting articles in this book including 'Tarikh-I Ahmad Shahi: The first history of 'Afghanistan"' by Amin Tarzi and "From Patriot to PortCity Poet: Mahmud Tarzi in Istanbul by Thomas Wide.

\section{The Afghan Way of War (2011) \\ Rating: UTTER RUBBISH \\ Rob Johnson \\ Hurst Publishers}

For those of you who were unfortunate enough to buy this book by a former British Army officer and Oxford based academic, I can only offer commiserations. The book is riddled with poor factual knowledge of Afghanistan and the geography of that strategic land. By way of example Johnson fails to correctly name the tribe which resides at the Khyber Pass or even the location of the pass which he wrongly believes lies between Jalalabad and Kabul. Little wonder then that the Brits found it so hard to combat the Taliban in Afghanistan when matters of basic geography are confusing for their officers, who then turn into 'illustrious' Oxford Academics like Robert Johnson:

\section{p.15 "Ghilzais astride the Khyber pass"}

The Ghilzai tribal area is not in the Khyber pass but lies between Kandahar, Ghazni and Kabul. The Afridis are the guardians of the Khyber pass. Indeed you yourself recognize the Khyber as the home of the Afridis when you state on page 51 "Akbar Khan feared treachery by the Afridis in the Khyber Pass region, and lacked funds to secure a passage so ...sending envoys to encourage the Afridis to resist any foreign force attempting to come from the East."

Further in relation to the geographic location of the Khyber Robson enlightens us not when he writes: 
p.72 As the British column struggled towards the Khyber Pass, each Ghilzai clan looked to acquire some sort of compensation ...(p.73) In the defiles of the Khyber Pass some Ghilzais attempted to halt the British column altogether with barriers....At the Khoord-Kabul pass, however the Ghilzais tried to kill as many foreigners as possible" The Khyber pass is situated between Jamrud and Ali Masjid in what was the North West Frontier of India/presently Khyber Pakhtunkhwa and the retreat from Kabul to Jellalabad does not take place via the Khyber but through the Khoord-Kabul pass. Robson's description on pages 72-73 confuses the issue by referring to a retreat through the Khyber. The EncylcopediaBrittanicadefines the Khyber as:

http://www.britannica.com/place/Khyber-Pass

This narrow gorge forms the Khyber Pass; it winds between cliffs of shale and limestone, 600-1,000 feet (180-300 m) high, and enters the Khyber Hills from the ShadiBagiār opening, a few miles beyond Jamrūd, Pak., and continues northwestward for about 33 miles $(53 \mathrm{~km})$. Just beyond the old Afghan fort of Haft Chāh, it opens onto the barren LowyahDakkah plain, which stretches to the Kābul River.

After a steep ascent at its southern entrance, the pass rises gradually to Fort Ali Masjid (3,174 feet), where the Khyber River (Khyber Khwār) leaves the pass to the south. For 5 miles from Ali Masjid the pass becomes a defile not more than 600 feet wide, flanked by imposing and precipitous walls."

p.24'Bellew who took part in the first Afghan war, was unimpressed by the Afghans" - The Bellew who served in the first Afghan war died on the retreat from Kabul in 1842. It was his son who was the administrator whom you refer to at the top of page 24 and whose book the 'Races of Afghanistan' (1880) you quote from in the same paragraph. This page confuses father and son as one person. In fact Henry Walter BellewMRCP (30 August 1834 - 26 July 1892) the author of books on Afghanistan was just 4 years old when the Army of the Indus was marching to invade Afghanistan. While Britain is known to use sixteen year old child soldiers up to the present day, it has not been known to use 4 year olds.

A litany of mistakes from our Oxford Academic friend Rob Johnson are detailed below:

P46 "Dost Mohammed ...emerged...to become the ruler of Ghazni and Kabul in 1826."Ghazni fell to D M Khan in 1837 see p.37 Noelle State and Tribe in Afghanistan

P47 Afghan Way of War "Dost Mohammed managed to mount an expedition against the Sikhs, winning a battle near Jamrud in 1836"

Not correct. 
p48 Afghan Way of War "Dost Mohammed Khan made a second attempt to defeat the Sikhs and his son Akbar Khan won an action in April 1837

This was in fact the second and only success.

P63 "The Reverend Gleig, who took part in the war"

Gleig points out he never was a veteran of the $1^{\text {st }}$ Anglo-Afghanistan war: "An accidental meeting with the $13^{\text {th }}$ regiment at the sea-bathing quarter of Walmer during the autumn of last year gave me an opportunity of hearing more of the particulars of the Jellalabad siege than had previously been communicated to me. The narrative was full of interest when detailed by actors in the scenes which they described" (p (v) Gleig Sale's Brigade in Afghanistan (London/1846)).

P.83 "At Qalat, Ghilzais of the Tokhi and Hotak clans had assembled very suddenly, having been uninvolved in the fighting before...it is difficult to determine why this brief aggression occurred" A bit of reading and research would have obtained the relevant information about why the Ghilzai rising occurred. Yet the lazy historiography that Johnson engages in precludes such research. My own work 'Afghanistan in the age of Empires' on the first Afghan war to be published later this year describes the reasons for the Ghilzai uprising during that war:

A Ghilzai rising in June 1840 was suppressed with considerable force by Nicholson and a Political Agent, a Lieutenant named E P Lynch became responsible for this area. The Ghilzai became silent for a time and Lynch with the military withdrew to Kandahar for the winter. However, come the new year the Ghilzai rose again and Rawlinson recommended stronger measures to quell the tribe. From Kelat-i-Ghilzai to Mokur live the western Ghilzai sub tribes of the Hotaki and Tokhi. Shortly after the invasion of Afghanistan, the tribal Chiefs had been displaced in favour of more pliable candidates. The new Chiefs were reluctant to chance their lives amongst their tribal compatriots and preferred the good life in Kandahar. So Leech recommended the establishment of a garrison at Kelat-i-Ghilzay to allow for the exercise of effective power. ${ }^{1}$ A fort was to be built on the great mound at Kelat-i-Ghilzai, which is on a prominent position alongside the Kabul to Kandahar road. On 21 April 1841 supported by a military force Lynch occupied the mound and during a ceremony attended by tribal chiefs, raised the flag of Shah Shuja. More alarmingly Lynch laid out his plans for a fort, which would contain accommodation for hostages. The Ghilzai chiefs were of course none too pleased to find out about Lynch's 'guest'quarters. Worse still Nicholson continued to wade in rivers of blood and nearly executed Walu Khan Shamalzay, a prominent Ghilzai related to the Ghilzai leaders who resisted the British invasion in 1839. This was despite the fact that Walu had a free pardon from another British officer. Nicholson hastily reversed his decision to

${ }^{1}$ Leech to Macnaghten, 3 Apr 1840, ESL 69, 22/64, 8 June 1840 cited at p.321 Yapp (1980) 
murder Walu, probably on Lynch's insistence, who immediately afterwards took Walu's sister as his mistress. To rub salt in the Ghilzai wounds, Walu's poor sister who had been sacrificed for her brother's life, was forced to stand beside Lynch at his ostentatious ceremony upon the mound of Kelat-i-Ghilzai to which the fuming Ghilzaichiefs, were invited as spectators. Lynch thereafter attacked a fort seven miles from Kelat-i-Ghilzai and killed most of the inhabitants in a move to deliberately make the Ghilzai submit to British domination. A trivial incident led to the massacre,

"Lynch, the political agent, was riding past a small fort, at some little distance, the next day, I believe accompanied by an escort of cavalry, he saw a body of men, 30 or 40 in number who retired as he advanced, towards the gate. To threaten them he galloped towards them with the cavalry, when they drew their swords, flourished them in the air, and the Chief (of the fort), one of Shah Soojah's most staunch adherents in those parts, sent word that no evil was meant, that the men had not understood the movement, and that he would pay his respects next morning; but this would not suit the fiery Lieutenant: an express was sent off for a regiment and the guns, which arrived in the course of the night; the place was attacked at once, a la Ghuznee, the gate blown in, and the fort stormed; all but four of the defenders of the place were killed, fighting desperately in the gate, the poor chief among their number, and two or three survivors wounded. This was trumpeted forth as a victory at first, but by degrees the facts have become known, and the matter exposed in its true light of wanton aggression and outrage for no purpose whatever, except to gratify the pique of vanity of the political agent, at the seeming want of courtesy of the Affghan Chief....The affair has not, however ended here, The Ghilzies, who are a powerful tribe of about 5,000 strong, turned out to a man, as might have been expected, and swore on the Koran to have revenge for the insult and injury, and for the innocent blood of their people. No attempt was made to pacify them... They are, however, determined to strike the first blow, and fell upon a detachment of the Company's troops of 400 infantry, some cavalry, and four guns, which were despatched to reinforce the garrison at KhelatiGhilzie. The attack was made at night, but was very gallantly repulsed, and many Ghilzies slain. Colonel Wymer was the commander of this detachment"2

Lord Auckland thought that Lynch had brought the taunts upon himself by flaunting British power in parading through the Ghilzai territory. Nor did Macnaghten approve of the move either, "Why should we go and knock our heads against mud forts?"3he

${ }^{2}$ Bombay July 201841 letter from an Indian officer in The Time 4 Sept 1841

${ }^{3}$ p.119 Vol.2 Kaye 
demanded to know. Shortly thereafter Lynch himself nearly succumbed to a Ghilzai uprising surrounded as he was upon his bare mound. Macnaghten discovered the facts about the imbroglio into which Lynch had placed himself and ordered his dismissal since Leech preferred"his private interests to those of public service" 4 and upon learning the full account of Lynchs' activities described him as "a very dangerous character". ${ }^{5}$ The fate of poor Walu's sister does not bear contemplating, Lynch may well have carried her off to India as his Ghilzai trophy, whom he would continue to enjoy as a 'comfort woman'. 6

In November 1841 the fort was complete and manned by Leech, who succeeded Lynch as political agent accompanied by a small military force. Male and more worryingly female hostages were also incarcerated in the fort. We do not know if the female hostages were subject to sexual abuse but given the antics of the occupying force, this must be more likely than not.These inmates were the relatives of Ghilzai tribesmen whom the British authorities wanted to detain and by way of emotional blackmail had captured their relatives. The detention of Afghan women was regarded as being particularly obnoxious by the tribesmen who made repeated demands for the freedom of these unfortunate women. However these demands fell on deaf ears. The Ghilzaitribe were empire builders and in the Eighteenth Century lived in Kandahar and extended their control over Persia. Later under Nadir Shah the Durranishad displaced this tribe from Kandahar. Now the double ignominy fell upon the Ghilzai of not only having lost their prominent position in Afghanistan to the Durranis, but also facing the humiliation of foreign occupation in their much reduced tribal territory. The newly built fort at Kelat-i-Ghilzai midway between Kabul and Kandahar,was a means of controlling the Ghilzaiwho bristled under the control of Kabul.

The eastern Ghilzais had stopped the British communications on the road between Kabul and Jalalabad. This was because Macnaghten had rashly cut payments to their Chiefs.

At Kelat-i-Ghilzai the dawn of the new year of 1842 would bring fresh challenges from the emboldened Ghilzai tribes who had learnt of the British defeat at Kabul.Captain Craigie was holding the fort at Kelat-i-Ghilzai supported by the political agent Robert Leech "A rapid in from Meer Alum with a letter to Leech advising him to give up the women as his keeping them will not gain him a good name either with the natives or Englishmen. He says that 5000 men are assembled at Candahar and they are awaiting the arrival of reinforcements and that he has been sent up here to take Kalat." ${ }^{7}$ The occupants of the fort were opposed by the Ghilzai tribesmen who would open fire whenever a suitable opportunity to target the troops presented itself. On 9 March the garrision at Kelat-i-Ghilzai learnt about the fall of Ghazni " reports the city to have fallen, through treachery within, the inhabitants some of whose houses abut on the walls of the town, are supposed to have (tunnelled a) way through from inside and thus let in their friends... This is a most extraordinary thing if true as from the way in the garrison was distributed about the town in barracks, it would be impossible to rally in time to escape.

\footnotetext{
${ }^{4}$ Macnaghten to Rawlinson (pte.) 29 June 1841 cited at page 323 Yapp Strategies of British India.

${ }^{5}$ Macnaghten to Rawlinson (pte.) 1 July 1841 cited at page 323 Yapp Strategies of British India.

'During the ISAF occupation Prisoner 650- The Grey lady of Bagram was the 'comfort woman' for US torturers who repeatedly raped her and this prisoner is widely believed to be Dr AafiaSiddique. Dr Siddique has been sentenced to a rather draconian term of 86 years in the USA for allegedly trying to shoot US troops in Ghazni during 2008. Dr Siddique was abducted from Karachi in 2003 and has remained in US imprisonment ever since.

${ }^{7}$ 23rd Feb 1842 Milne Diary NAM
} 
Previous to the taking of the town, Col Palmer had taken hostages from the town's people and that as soon as treachery was uncovered, he blew them from a Gun. "8 By 17th March the British force under Colonel Palmer had surrendered the citadel to the Afghans due to lack of water. ${ }^{9}$

The lives of the Afghan hostages were at stake as tensions rose at Kelat-I-Ghilzai. By April the Ghilzai were suitably reinforced to attack the fort and liberate the poor Ghilzai female hostagesfrom the grips of the troops. On 16 April there was a further request from the Afghan side to release families held hostages, which was not complied with. On 14th May the Afghans promised to disperse their forces besieging Kelat-i-Ghilzai if the Afghan prisoners were released, but this final offer was declined by Leech. By 19th May the siege was tightening, "They have ...thrown up these breastworks wherever the ground is at all favourable to them, and really they have made very respectable defences and well calculated from positions to afford protection to each other". From these breast works the Tureekees keep up a fire whenever any person shows himself especially an officer whom they distinguish by us wearing white cap covers within the last 2 days they have fired no less than 2000 rounds and yet they have wounded no one"10.

"Kelat-i-Ghilzai was attacked in two places, at $1 / 4$ to 4 o'clock this morning, viz at the long neck to the N.E and at an outwork constructed last winter by the sepoys to give a raking fire in rear of the Barracks.

The enemy advanced to the assault in the most determined manner, each column consisting of 2000 men, provided with 30 scaling ladders, but after an hours fighting were repulsed and driven down the hill losing five standards which are now in our possession. Off the enemy's loss I am unable to give an accurate account as their killed and wounded during the greater part of the attack were immediately taken to be dead, but 194 dead bodies were left on the slope of the hill and from 6am till 3pm the enemy were employed in carrying off such of their dead and wounded....

The opportunity we have been for so long looking for arrived this morning, it has put us all in high spirits, which were however a little dampened, by the necessity which arose of shooting and bayoneting the male prisoners who as soon as the firing became heavy ... attempted to escape." ${ }^{11}$ By 1st June the fort at Kelat-i-Ghilzai had been dismantled by the British and the troops evacuated. We do not learn if the female hostages were ever freed or were eventually taken back to India as 'comfort women'. Certainly Robert Leech the political agent had a reputation as someone who like Burnes, was a great 'admirer' of Afghan women and it seems unlikely that he would not want to take advantage of the Ghilzai female hostages: ${ }^{12}$ (p229-230 Afghanistan in the Age of Empires: the great game for south and Central Asia)

In conclusion, the scope of this work is broad, but the author's research skills are negligible. I can only hope that this work was not the doctoral dissertation for this academic since it is of such poor quality as to be unworthy of an academic.

\footnotetext{
${ }^{8}$ Milne diary NAM

${ }^{9}$ Milne diary NAM

${ }^{10}$ Milne Diary NAM

${ }^{11}$ Milne diary NAM

${ }^{12}$ See p.43 Sir Henry Marion Durand The First Afghan war and its causes
} 